Policy Research Working Paper 2405

\section{Marginal Willingness to Pay for Education and the Determinants of Enrollment in Mexico}

Gladys Lopez-Acevedo

Angel Salinas
The best way to increase school enrollment in Mexico is to successfully target public spending on education to poor households. Currently, nompoor households in urban areas get much of the subsidy benefit from the government provision of education services.

The World Bank

Latin America and the Caribbean Region

Economic Policy Sector Unit

and

Mexico Country Office

July 2000 
Policy Research Working Paper 2405

\section{Summary findings}

Standard benefit-incidence analysis assumes that the subsidy and quality of education services are the same for all income deciles. This strong assumption tends to minimize the distributional inequity at various education levels.

Using a new approach emphasizing marginal willingness to pay for education, Lopez-Acevedo and Salinas analyze the impact of public spending on the education spending behavior of the average household.

They address several questions: What would an average household with a given set of characteristics be willing to spend on an individual child with given traits if subsidized public education facilities were unavailable? What would the household have saved by sending the child to public school rather than private school? How great are these savings for various income groups? What are the determinants of enrollment by income group and by location? How do individuals' education expenditures affect enrollment patterns?

Among their findings:

- The nonpoor households in urban areas get much of the subsidy, or "savings," from government provision of education services.
- The wealthy value private education more than the poor do.

- Differences in school quality are greater at the primary level.

In other words, wealthy households get the lion's share of benefits from public spending on education.

Household school enrollment and transition to the next level of schooling depend heavily on the cost of schooling, how far the head of the household went in school, the per capita household income, and the housing facilities or services. But the government's effort also affects the probability of enrollment and transition.

The probability of enrollment is much higher for the 40 percent of higher-income households in urban areas than it is for the 40 percent of lower-income households in rural areas.

The best way to increase school enrollment is to successfully target public spending on education to poor households.

This paper-a product of the Economic Policy Sector Unit and the Mexico Country Office, Latin America and the Caribbean Region--is part of a strategy to reduce poverty and inequality in Mexico. The study was part of the research project "Earnings Inequality after Mexico's Economic Reforms." Copies of this paper are available free from the World Bank, 1818 H Street NW, Washington, DC 20433. Please contact Michael Geller, room I4-142, telephone 202-458-5155, fax $202-$ 522-2093, email address mgeller@worldbank.org. Policy Research Working Papers are also posted on the Web at www.worldbank.org/research/workingpapers. The authors may be contacted at gacevedo@worldbank.org or asalinas@worldbank.org. July 2000.(22 pages)

The Policy Research Working Paper Series disseminates the findings of work in progress to encourage the exchange of ideas about development issues. An objective of the series is to get the findings out quickly, even if the presentations are less than fully polished. The papers carry the names of the authors and should be cited accordingly. The findings, interpretations, and conclusions expressed in this paper are entirely those of the authors. They do not necessarily represent the view of the World Bank, its Executive Directors, or the countries they represent. 


\title{
Marginal Willingness to Pay for Education and the Determinants of Enrollment in Mexico
}

\author{
Gladys Lopez-Acevedo (LCSPE) and Angel Salinas (LCC1C) ${ }^{1}$
}

\begin{abstract}
$\underline{\text { Abstract }^{2}}$
Standard benefit-incidence analysis assumes that the subsidy and the quality of educational services are the same for all income deciles. This is a strong assumption that has the tendency to minimize the distributional inequity within educational levels. This paper uses a new approach, which prevents this drawback. The marginal willingness to pay analysis measures the government's provision for public schools effect on the educational spending behavior of an average household. In analyzing the impact of public spending on household behavior, this paper focuses on the following questions: What would an average household $h$ with a given set of characteristics $(\mathrm{Xh})$ willing to spend on an individual child $\mathrm{i}$ with traits $(\mathrm{Xc})$, if subsidized public education facilities were not available? What would the household have "saved" by sending the child to public schools instead of private schools? How large are these "savings" for various income groups? Which are the determinants for enrollment by income groups and location? How do individuals' educational expenditures affect enrollment patterns?

Among some of the most interesting findings that this paper shows are: i) the non-poor and those in urban areas get a large share of the subsidy or "savings" from the government provision of educational services. ii) The valuation for private educational services is higher for the wealthy as compared to for the poor. iii) School quality differences are higher at primary level. These results reinforce the finding that those households with a high level of educational expenditures get the largest subsidy from public educational services.

On the demand side, household school enrollment and transition patterns are highly dependent on the cost of schooling, head of household's educational level, dwelling services and household income per capita. On the supply side, the government's effort greatly affects the probability of enrollment and transition. The probability of school attendance is much higher for the top $40 \%$ of the income distribution in urban areas when compared to those in the bottom $40 \%$ in rural areas. The variable government effort has a significant marginal impact which is many times larger for the 'Poor' as compared to the 'Wealthy' (in elasticity terms, this variable is more effective for the poor by a factor of 12 and by a factor of 15 in rural areas). The differential impact suggests that the goal of efficiency in terms of maximizing enrollments in secondary school level does not have a trade-off with the goals of greater equity educational opportunity. Indeed, these findings indicate that increases in enrollment will be more readily obtained if resources are successfully targeted towards the poorer income group.

The paper is part of a comprehensive work meant to build a poverty and inequality strategy for Mexico.
\end{abstract}

\footnotetext{
${ }^{1}$ This research was completed as part of the "Earnings Inequality after Mexico's Economic and Educational Reforms" study at the World Bank. We are grateful to INEGI and SEP (Ministry of Education) for providing us with the data. These are views of the authors, and need not reflect those of the World Bank, its Executive Directors, or countries they represent.

2 This paper was prepared with research support from Monica Tinajero.
} 

Standard benefit-incidence analysis assumes that the subsidy and the quality of educational services are the same for all income deciles. This is a strong assumption that has the tendency to minimize the distributional inequity within educational levels. This paper uses a new approach that prevents this drawback. The marginal willingness to pay analysis measures the government's provision for public schools effect on the educational spending behavior of an average household. What would an average household with a given set of characteristics be willing to spend on an individual child, if subsidized public education facilities were not available? What would the household have "saved" by sending the child to public schools instead of private schools? How large are these "savings" for various income groups?

In addition, this paper investigates the link between the government's educational policy and the household's decision-making with regards to its educational expenditure and schooling enrollment. Consequently, this paper focuses on answering the following questions: Which are the determinants for enrollment by income groups and location? How do individuals' educational expenditures affect enrollment patterns?

The study is structured as follows: Section 1 provides a brief description of the data. Section 2 examines private expenditures on education. Section 3 studies the determinants of upper secondary enrollment. Section 4 analyses the marginal willingness to pay for educational services. Section 5 presents the concluding remarks.

\section{THE DATA}

This paper uses the data from the National Household Income and Expenditures Survey (ENIGH) for 1996. The ENIGH is collected by the Instituto Nacional de Estadistica, Geografia e Informática (INEGI). This survey is available for 1984, 1989, 1992, 1994 and $1996^{3}$. Each survey is representative at national level, urban and rural areas. For 1996, the ENIGH is also representative for the states of Mexico, Campeche, Coahuila, Guanajuato, Hidalgo, Jalisco, Oaxaca and Tabasco.

The survey design was stratified, multistage and clustered. The final sampling unit is the household and all the members within the household who were interviewed. ${ }^{4}$ In each stage, the selection probability was proportional to the size of the sampling unit. Then, it is necessary to use the weighs ${ }^{5}$ in order to get suitable estimators. The available information can be grouped in three categories:

- Income and consumption: the survey has monetary, no monetary and financial items.

- Individual characteristics: social and demographic, i.e., age, school attendance, level of schooling, position at work, economic sector, etc.

- Household characteristics.

In addition, data from the Direccion General de Planeacion, Programacion y Presupuesto (DGPPyP, Ministry of Education) regarding educational government expenditures (Federal plus state) assigned to the different levels of schooling for each state is used in order to calculate the unit costs.

\footnotetext{
${ }^{3}$ The sample in a given year is independent from another.

4 The sample size for 1996 is as follows: households 14,042 and individuals 64,359 .

${ }^{5}$ The weights should be calculated according to the survey design and corresponds to the inverse of the probability inclusion.
} 
On the demand side, household enrollment patterns are highly dependent on the cost of schooling. The total monetary cost for the household, without considering the opportunity cost, comprises school fees, tuition and unforeseen expenses, transportation cost, textbooks, stationery, and uniforms. Table 4 in appendix 1 shows how much an average household spend on education by poverty status and educational level. Table below illustrates the fact that most students who are in private schools spend in education more than twice than those students who are in public schools. As it can observed in this table, the share of the expenditures in services and materials are similar for both private and public school, while the fees and unforeseen expenses constitute the differences in total school expenditures between private and public schools. In private schools, fees and unforeseen expenses account for $70 \%$ of the school expenditures compared to $38 \%$ in public schools. Moreover, the educational expenditures in the urban areas are twice as high as in rural areas (see table 5 in appendix 1).

Table 1. Household Expenditure in Education by Poverty Status, 1996

\begin{tabular}{|c|c|c|c|c|c|c|c|}
\hline \multirow[t]{2}{*}{ Poverty Status } & \multicolumn{3}{|c|}{ Expenditures per student $(\%)$} & \multirow[b]{2}{*}{ Total } & \multirow{2}{*}{$\begin{array}{c}\text { Educational } \\
\text { Expenditures } \\
(\%)^{2 /}\end{array}$} & \multirow{2}{*}{$\begin{array}{c}\text { Services, materials } \\
\text { Expenditures } \\
(\%)^{2 \prime}\end{array}$} & \multirow{2}{*}{$\begin{array}{l}\text { Number of } \\
\text { Households }\end{array}$} \\
\hline & $\begin{array}{c}\text { Fees/Unforeseen } \\
\text { expenses }\end{array}$ & Services & Materials ${ }^{1 /}$ & & & & \\
\hline \multicolumn{8}{|l|}{ Private schools } \\
\hline Extreme & 70.3 & 1.0 & 28.7 & 100.0 & 14.6 & 4.3 & 12 \\
\hline Moderate & 75.1 & 4.3 & 20.7 & 100.0 & 11.1 & 2.8 & 50 \\
\hline Non poor & 70.8 & 5.5 & 23.7 & 100.0 & 16.7 & 4.9 & 499 \\
\hline Total & 70.9 & 5.4 & 23.7 & 100.0 & 16.6 & 4.8 & 561 \\
\hline \multicolumn{8}{|l|}{ Public schools } \\
\hline Extreme & 32.2 & 1.2 & 66.6 & 100.0 & 6.3 & 4.3 & 2825 \\
\hline Moderate & 35.2 & 2.4 & 62.4 & 100.0 & 7.0 & 4.5 & 2511 \\
\hline Non poor & 41.8 & 5.4 & 52.7 & 100.0 & 6.7 & 3.9 & 2544 \\
\hline Total & 38.3 & 3.8 & 57.8 & 100.0 & 6.7 & 4.2 & 7880 \\
\hline
\end{tabular}

Source: ENIGH 96

1/ Textbooks, stationery, etc.

2/ As percentage of household's expenditures

Table 2 below compares the expenditure of poor and non-poor students by education level, showing significant disparities. At primary level, non-poor students in public school spend four times the amount than extreme poor students spend in education. While at the university level non-poor individuals spend 1.4 times as much as poor students. These differences might be partly explained by scholarships or discounts on tuition fees among the poor.

Information at the individual level on schooling expenditures is available only for school fees, tuition and unforeseen expenses, but assuming that the amount spend on materials and services is fixed for all levels of education, the individual total educational expenditures are much lower than the government subsidy. In fact, the public subsidy compared to the average student expenditure is 2.8 times for primary level, 2.3 for lowe- secondary, 2.2 for upper secondary and 5.2 for university. 
Table 2. Expenditures in Education per Student (Fees/tuition/unforeseen expenses) ${ }^{1 /}$ by Level of Education, 1996

\begin{tabular}{lcccc}
\hline \multicolumn{1}{c}{ Poverty Status } & Primary & Lower Secondary & Upper Secondary & Tertiary \\
\hline Public and Private schools & 76.7 & 268.2 & 851.9 & 1828.7 \\
Extreme & 186.3 & 491.6 & 975.9 & 835.9 \\
Moderate & 1378.9 & 1404.7 & 2965.1 & 5448.7 \\
Non poor & 425.4 & 750.1 & 1996.2 & 4466.8 \\
Total & & & & \\
Public schools & 74.6 & 262.4 & 760.1 & 1828.7 \\
Extreme & 179.4 & 485.2 & 883.7 & 817.4 \\
Moderate & 307.4 & 712.5 & 1292.1 & 2577.7 \\
Non poor & 156.8 & 492.9 & 1057.4 & 2141.6 \\
Total & & & & \\
Private schools & 1422.5 & 1252.5 & 2845.0 & 0.0 \\
Extreme & 1739.0 & 1088.7 & 2540.3 & 1179.4 \\
Moderate & 6468.1 & 6539.0 & 8515.2 & 12950.5 \\
Non poor & 6241.9 & 5915.4 & 7495.3 & 12451.3 \\
Total & & & \\
\hline Source: ENIGH & & & & \\
\hline
\end{tabular}

Source: ENIGH 96

1/ Annual pesos per student

The total cost (student expenditure plus government subsidy) per student in primary public school corresponds to about $35 \%$ of the private primary school cost. For students in lower and upper secondary it represents $43 \%$ and $53 \%$, respectively. On the other hand, the cost of tertiary level is $13 \%$ higher in public schools as compared to private (see tables below). An interesting question that arises is why the cost at tertiary level is higher in public than in private schools. Is it because the subsidy is not being used efficiently, or because the infrastructure (research institutes, libraries, museums, entertainment centers, etc.) they offer is costly?

In the next section a technique is applied that will allow us to evaluate the impact of public expenditures on household spending patterns.

Table 3. Individual Educational Expenditures" plus Subsidy in Public Schools by Poverty Status ${ }^{2 /}$

\begin{tabular}{lcccc}
\hline Poverty Status & Primary & Lower Secondary & Upper Secondary & Tertiary \\
\hline Extreme & 2799 & 3266 & 5002 & 16970 \\
Moderate & 3267 & 3852 & 5489 & 16322 \\
Non poor & 3941 & 4626 & 6444 & 18629 \\
Total & 3268 & 3883 & 5686 & 17670 \\
\hline
\end{tabular}

Source: ENIGH 96 and DGPPyP, SEP

"Fees/tuition/unforeseen expenses, services and materials, 2/ Annual pesos

Table 4. Individual Educational Expenditures ${ }^{1 /}$ in Private Schools by Poverty Status ${ }^{2 /}$

\begin{tabular}{lcccc}
\hline Poverty Status & Primary & Lower Secondary & Upper Secondary & Tertiary \\
\hline Extreme & 2295 & 2125 & 3717 & \\
Moderate & 2390 & 1740 & 3191 & 1831 \\
Non poor & 9851 & 9922 & 11898 & 16334 \\
Total & 9387 & 9060 & 10640 & 15596 \\
\hline
\end{tabular}

Source: ENIGH 96 and DGPPyP, SEP

1/ Fees/tuition/unforeseen expenses, services and materials, 2/ Annual pesos 
The preliminary results on the pattern of individual expenditures with children in public schools suggest that the burden on poor households can be substantial, and that it is unlikely that a poor household would afford to attend a private school ${ }^{6}$.

\section{ESTIMATING THE EFFECT OF GOVERNMENT SPENDING ON HOUSEHOLD EDUCATIONAL EXPENDITURES}

Looking at the impact of public educational expenditures by deciles, it is usually assumed that the subsidy and the quality of education are uniformly the same for all income deciles. This is a strong assumption that tends to minimize the distributional inequity within educational levels. The Marginal Willingness to pay approach prevents this drawback and estimates a willingness to pay equation for private school services corrected for self-selection bias, using standard Heckman methodology. Appendix 2 reviews this methodology.

In analyzing the impact of public spending on household behavior, one could ask the following questions: What would an average household $h$ with a given set of characteristics $(X h)$ be willing to spend on an individual child $i$ with traits $(X c)$, if subsidized public education facilities were not available? What would the household have "saved" by sending the child to public schools instead of private schools? How large are these "savings" for various income groups?

Intuitively, one would think that household "savings" could be estimated as the difference in household education spending on public versus private schooling of children of comparable characteristics. While the concept appears straightforward, the estimation is not. The challenge is to ensure that these two groups of children are comparable. One can argue that due to observable and unobservable factors, the two groups of children are in fact different. Examples of measurable variables are family income and parents' education. Examples of unobserved variables that can generate self-selection bias is preference for religious instruction, high rate of return to quality due to child's exceptional intelligence, and taste for individualized instruction. Lack of control for these unobservable factors would overstate the potential household "savings" associated with the provision of subsidized public education. Households send their children to private schools despite availability of public school places, because they want higher quality and additional services that they cannot find in public schools.

The Heckman's methodology starts by estimating a probit equation. The probit equation or step 1 (see appendix 2) has as dependent variable whether child $i$ is attending private school (value of 1) or public school (value of 0 ). The explanatory variables are per capita household income, years of school of household head (hh), area (urban/rural), age, gender, number of rooms, type of floor and number of children in household. The trigger variable that identifies the model is the number of students per classroom, by type of education at municipal level. Table 5 provides the results of the estimation.

\footnotetext{
${ }^{\circ}$ An illustration of the disproportional burden of education on the poor can be obtained by comparing household expenditures on education with non-food expenditures per capita.
} 
Table 5. Probit on Private School Attendance

\begin{tabular}{l|cc|c}
\hline Explanatory & Coefficient & $\begin{array}{c}\text { Marginal } \\
\text { Effect }\end{array}$ \\
Variable & 0.78 & $*$ & 0.064 \\
Per capita income & 0.03 & $*$ & 0.002 \\
Years of schooling of head & 0.80 & $*$ & $0.046+$ \\
Area (rural) & 0.16 & $*$ & 0.014 \\
Age & 0.00 & $*$ & 0.000 \\
Age squared & -0.12 & $* *$ & -0.010 \\
Gender (female) & 0.09 & $*$ & 0.008 \\
Number of rooms & 0.40 & $*$ & 0.037 \\
Floor (not finished floor) & 0.32 & $*$ & 0.024 \\
Sewage (not sewage) & -0.10 & $*$ & -0.008 \\
Number of Children & -0.09 & $*$ & -0.008 \\
Trigger Variable & -7.56 & $*$ & \\
Constant & \multicolumn{2}{|l}{} \\
Source: Own calculations based on ENIGH 96 and DGPyP, SEP \\
* Significant at 5\% \\
** Significant at 10\% \\
Italics indicates the reference category for dichotomous variables \\
(+) dF/dx stands for the discrete change in the dummy variable from 0 to 1
\end{tabular}

The first column on table 5 has the coefficient and the second shows the marginal effects as estimated from the probit. ${ }^{7}$ Notice that all explanatory variables are significant at $5 \%$ level, except for gender. In addition, all explanatory variables show the expected sign on the probability to attend private school. For instance, the probability to attend private school is positively influenced by per capita household income and area.

The household's willingness to pay for private education ( $P v)$ of child $i$ (step 2) in Heckman's methodology is estimated using total educational expenditures on private schools (fees, tuition, unforeseen expenses and school materials ${ }^{8}$ ) as dependent variable. ${ }^{9}$ Explanatory variables are Mills' ratio and the variables from the probit estimation except the trigger variable ${ }^{10}$.

Using the estimates from step 2 and step 3 and the mean of all explanatory variables, one can compute the amount of money that households would be willing to pay for the child's private education ( $M M W P v$, step 4) or public education ( $M M W P u$, step 5). Notice that the difference between $M M W P v$ and $M M W P u$ measure the effect of the government provision of public schools on the education spending behavior of an average household. Note that this difference reflects the relative quality and payments (fees and unforeseen expenses) associated with public and private schools.

Next, how large household "savings" is computed for different population subgroups by area, poverty status, educational level and total educational expenditures by quantile.

Tables 1 through 9 in appendix 2 show the average values of the explanatory variables for the different population subgroups. Beforesaid, these values are used to compute the marginal willingness to pay corrected for self-selection bias. ${ }^{11}$

As indicated on table 1 in appendix 2 , all the explanatory variables turned are significant in the process of computing the marginal willingness to pay for public educational service except for gender. In the case of private education, the relevant variables are income, years of schooling of the head of the household and sewage.

\footnotetext{
${ }^{7}$ The marginal effect for continuous variables is the marginal effect as evaluated at the mean of the particular exogenous variable. Dichotomous variables have been coded as ' 0 ' or ' 1 ', and the marginal effect for such variables represents the impact of the probability of having a ' 1 ' value for the exogenous variable, as compared to a ' 0 ' value, the other variables being held constant at their mean values.

${ }^{8}$ Included only those students with positive fees, tuition and unforeseen expenses.

${ }^{9}$ Step 3 uses public educational expenditures instead of private ones.

${ }^{10}$ See appendix 2.

"Note that it is not possible to compare directly actual average payments with the marginal willingness to pay since the later controls for observed factors.
} 
Table 6. Effect of public schools provision on an average household education spending ${ }^{1 /}$

\begin{tabular}{ll}
\hline MMWPv & 6274.88 \\
MMWPu & 1080.92 \\
\hline Effect or "savings" & 5193.96 \\
\hline $\begin{array}{l}\text { Source: Own calculation based on ENIGH } 96 \\
\text { 1/ Annual 1996 pesos }\end{array}$
\end{tabular}

Assuming that there are no differences in the quality of education between a public and a private school, it is seen in table 6 (after controlling for observed and unobserved factors) that family's savings from sending a child to a public school amount to approximately $\$ 5,000$ pesos per year (0.56 minimum wages in 1996). In addition, the results suggest that such savings are correlated with the schooling of the household head, location and number of children at home.

Now, assuming that the difference between private and public schools students' scores is only $10 \%$, then, ninety percent of the effect or "savings" is due to relative payments and unforeseen expenses. The rest will reflect the amount that the average child would have to pay for "quality difference" in moving from a public to a private school.

The marginal willingness to pay desegregated by area is shown on table 7. Supposing that the quality between public and private schools in both rural and urban areas is the same, then, it turns out that the government provision of public schools is higher in urban areas than in rural areas. This result could be explained among other things, by the following factors: (i) poor location of public educational services; (ii) distance that an individual has to travel to the nearest school; (iii) the population dispersion and lastly the opportunity cost of the children in rural areas.

On the other hand, assuming that there is not a quality difference between private-public schools in rural areas and the quality difference between public-private schools in urban areas is a little above $50 \%$, the relative payments and unforeseen expenses would be the same in both areas. Finally, assuming that the quality difference between public and private rural schools is zero but the quality difference in urban areas is $10 \%$, then the relative payments and unforeseen expenses (as part of the "effect") in urban areas is higher than in rural areas (urban effect $\$ 4,016$ pesos and rural effect $\$ 2,245$ pesos). In summary, such scenarios suggest that students in urban areas get a larger share of the subsidy or "savings" from the government provision of educational services compared to these in rural areas.

Table 7. Effect " of public schools provision on household education spending by area

\begin{tabular}{lcc}
\hline & Urban & Rural \\
\hline MMWPv & 6459 & 2674 \\
MMWPu & 1438 & 429 \\
Effect & 5021 & 2245 \\
\hline
\end{tabular}

Source: Own calculation based on ENIGH 96

1/ Annual 1996 pesos

As shown on table 8, the government provision to public schools has a smaller impact on the poor as compared to the non-poor. Notice on table 4 in appendix 2, that for both poor and nonpoor, gender is not important in the determination of the $M M W P u$, while per capita household income, age, and number of children do have an impact. It is important to note that while the education of the household head determines the $M M W P u$ for the poor, it does not affect it for the non-poor. With respect to $M M W P v$ for poverty status, table 5 in appendix 2 shows that the educational level of the household head affects the $M M W P v$ for both groups, while the per capita household income does affect the non-poor. The age of the children impacts on the $M M W P v$ of the poor, but it does not have any effect on the non-poor. Finally, again gender is not important in the $M M W P v$ for the poor as well as the non-poor.

The analysis by poor/non-poor and region suggests the following: i) the non-poor and those in urban areas get a large share of the subsidy or "savings" from the government provision of education services; and ii) the valuation for private educational services is higher for the wealthy as compared to for the poor. In light of these results, plausible alternatives for the government 
include: (i) to better target public educational services; (ii) charge a fee for public educational services to the non-poor; and (iii) increase the quality of educational services for the poor.

Table 8. Effect ${ }^{1 /}$ of public schools provision on household education spending by poverty status ${ }^{12}$

\begin{tabular}{lccc}
\hline & Extreme & Moderate & Non Poor \\
\hline MMWPy & 2114.63 & 2963.22 & 7229.76 \\
MMWPu & 849.23 & 1241.22 & 1073.99 \\
Effect & 1265.40 & 1722.00 & 6155.77 \\
\hline
\end{tabular}

Source: Own calculation based on ENIGH 96

1/ Annual 1996 pesos

As follows from table 6 in appendix 2, at the primary level, all explanatory variables turned are significant for explaining the $M M W P u$. In lower secondary level, the variables household per capita income, region, number of rooms, type of floor and number of children are important in the determination of the $M M W P u$. While for upper secondary instruction, household per capita income and age are relevant. Interestingly, household per capita income is also a significant variable in explaining $M M W P v$ (see table 7 in appendix 2). This suggests that parent's valuation for private educational services relies solely on income while for public educational services there are other important factors in addition to income that determines $M M W P u$.

In table 9 , the effect of government provision of school services is very similar for both primary and lower secondary schooling level (basic education). ${ }^{13}$ This effect is higher in basic education as compared to upper secondary or technical education. Assuming that the quality difference between private and public schools is only $10 \%$ for all levels of education, relative payments and unforeseen expenses ("savings") will be much higher in basic school as compared to upper secondary level. For primary through upper secondary level, there is a positive decreasing relationship between the payments difference (in private versus public schools) and instruction level. Allowing such difference to be a proxy for quality, then, the quality difference between private and public schools in primary level is $70 \%$, in lower secondary is $60 \%$ and in upper secondary is $50 \%$. This indicates that quality differences are higher in primary level. The remaining savings are due to payments and provisions.

Table 9. Effect ${ }^{1 /}$ of public schools provision on household education spending by educational level

\begin{tabular}{lccccc}
\hline & $\begin{array}{c}\text { Pre } \\
\text { Primary }\end{array}$ & Primary & $\begin{array}{c}\text { Lower } \\
\text { Secondary }\end{array}$ & $\begin{array}{c}\text { Upper } \\
\text { Secondary }\end{array}$ & $\begin{array}{c}\text { Technical } \\
\text { Education }\end{array}$ \\
\hline MMWPv & 5856.12 & 6920.00 & 8024.88 & 7156.88 & 3688.08 \\
MMWPu & 880.36 & 714.68 & 1725.68 & 2541.96 & 2539.2 \\
Effect & 4975.76 & 6205.32 & 6299.2 & 4614.92 & 1148.88 \\
\hline
\end{tabular}

Source: Own calculation based on ENIGH 96

1/ Annual 1996 pesos

In addition to Least Squares Regression (LSR), quantile regressions ${ }^{14}$ were computed to test for robustness of the above results. The aim is to assess how large these "savings" are for various educational expenditure groups. Results of this test indicate that the distribution of "savings" might be right-skewed since the $M M W P u, M M W P v$ and the savings effect, evaluated at the median of the total educational expenditure distribution, are lower than in the LSR. Note that at the median of the public educational expenditures distribution all explanatory variables are significant for explaining $M M W P u$ (see table 8 in appendix 2). Yet, at the tails of this distribution, variables such as gender, number of children and schooling of the household head are not significant in explaining $M M W P u$.

\footnotetext{
12 If we assume that the income distribution for the extreme poor is uniform, therefore an average poor household will get $\$ 9510.00$ annual 1996 pesos (it is assumed that the household average size is 5 and that the poverty extreme line is $\$ 317.00$ monthly per capita 1996 pesos).

${ }^{13}$ The analysis was not performed for the tertiary level because the "trigger variable" was not available at that level of education.

${ }^{14}$ See appendix 3 for a brief review of the quantile regression technique.
} 
Another observation is that at the median and lower tail of the private educational expenditure distribution, variables such as income, household head schooling and housing facilities are important to determine the $M M W P v$. At the upper tail of the distribution, household per capita income is the only relevant variable that determines $M M W P v$ (table 9 in appendix 2).

Table 10. Effect ${ }^{1 /}$ of public schools supply on household education spending through out the conditional ${ }^{15}$ expenditure distribution

\begin{tabular}{lccccc} 
& Quantile & Quantile & Quantile & Quantile & Quantile \\
& $\mathbf{0 . 1}$ & $\mathbf{0 . 2 5}$ & $\mathbf{0 . 5}$ & $\mathbf{0 . 7 5}$ & $\mathbf{0 . 9}$ \\
\hline MMWPv & 1101.48 & 2843.56 & 5781 & 16291.04 & 39533.6 \\
MMWPu & 16.52 & 252.12 & 1636.2 & 6241.2 & 12897.04 \\
Effect & 1084.96 & 2591.44 & 4144.84 & 10049.88 & 26636.56 \\
\hline
\end{tabular}

Source: Own calculation based on ENIGH 96

1/ Annual 1996 pesos

It is seen from the above analysis and from table 10 that those households with a high level of educational expenditures receive the largest subsidy from public educational services. Given that there is a strong positive relationship between educational expenditures and per capita household income, a reasonable conclusion might be that the government should charge a fee to those in the upper tail of the income distribution especially considering that the wealthy individuals have both a high valuation for quality of schooling and are able to pay for the educational service.

\section{FACTORS THAT DETERMINE UPPER SECONDARY ENROLLMENT}

Next, the factors that determine enrollment in upper secondary school level are analyzed. ${ }^{16}$ This is done in order to assess which household and government variables affect enrollment and retention at upper secondary level.

For purpose of the following analysis, the probability being modeled is enrollment in upper secondary school for individuals age 15 to 19 , the official school age for this level of education. The child and household level variables are: (a) demographic variables, including the number of babies, children, and adults, as well as the square of the number of babies, children, and adults, the age of the household head and its square, and the household head gender; (b) the age and age squared of the child; (c) education variables: the educational level of the head in categories (some primary school, primary school completed, lower secondary complete, upper secondary complete and higher); and (c) occupation variables: the household head's industrial sector of employment and position occupied, as well as an indicator for the formal sector. The government variables are measured at state level and include: federal expenditures in 1996 pesos per student at both the basic and upper secondary school level and the number of teachers per thousand individuals in age range 15-19.

Table 1 in appendix 4 presents the marginal effects as estimated from the probits for znrollment at a national level as well as the impact of the exogenous variables across the income distribution and through urban and rural areas. This is of interest in the exam of the impact of government subsidies and schooling variables on the poor. If government concerns for equity are translated into higher school enrollment, one might expect to see a stronger impact of government transfers and a supply of educational services for the poorer income groups and rural areas, as opposed to the relatively wealthy groups. Table 1 in appendix 4 also shows the probit regressions results run separately on for the 'Poor' and "Wealthy" income groups, which in turn are formed by the bottom $40 \%$ and the top $40 \%$ of the income distribution.

\footnotetext{
${ }^{15}$ Conditional to per capita income, years of schooling of head, area (rural), age, age squared, gender, number of rooms, type of floor, sewage, number of children, trigger variable.

${ }^{16}$ For a review of factors that affect basic education enrollment, see World Bank (1999). Government Programs and Poverty in Mexico, Green Cover.
} 
For the overall population, the probability of enrollment is positively influenced by head of household's educational level after lower secondary, dwelling's services such as sewage and household income per capita. Aside from being sewage an important indicator of family wealth, the absence of sewage suggest the possible necessity for children to be involved in a greater number of household chores. The positive marginal effects from such variable increases by $7 \%$ the probability of enrollment.

Variables with a negative influence include student's age, female gender (not significant) and family size. Note the $12 \%$ negative impact of some primary schooling for the household head in the poorer group, as compared to the statistically insignificant impact of this variable on enrollment probability amongst the richer group. Similarly, household head income per capita has a 5\% positive impact on the probability of enrollment in urban areas, and the impact of household head income per capita is absent among the rural.

Table 11. Determinants of Upper Secondary School Enrollment

\begin{tabular}{lccccc}
\hline & Full Sample & Poorest 40\% & Richest 40\% & Urban & Rural \\
\hline Probability of enrollment & 0.66 & 0.49 & 0.82 & 0.73 & 0.39 \\
Mean Income & 7.44 & 6.63 & 8.14 & 7.56 & 7.03 \\
Mean teachers & 1.89 & 1.80 & 1.95 & 1.90 & 1.84 \\
Income Elasticity & 0.58 & -1.11 & 0.44 & 0.53 & 0.11 \\
Teachers Elasticity & 0.20 & 0.49 & 0.04 & 0.08 & 1.19 \\
\hline
\end{tabular}

Source: Own calculations based on ENIGH 96

As can be seen on table 11, the probability of enrollment in upper secondary is much higher for both the top $40 \%$ of the income distribution and in urban areas as compared to those in the bottom $40 \%$ and in rural areas. The variable teachers (government effort) has a significant marginal impact which is many times larger for the 'Poor' as compared to for the 'Wealthy' and for rural areas as compared to urban areas. In elasticity terms, the teacher's variable is more effective for the poor and for the rural areas by factors of 12 and 15, respectively. The differential impact suggests that the goal of efficiency in terms of maximizing enrollments in upper secondary school does not have a trade-off with the goals of greater equity of educational opportunity. Indeed, the above findings indicate that increases in enrollment will be more readily obtained if resources are successfully targeted towards the poorer income group. It is of interest to note the negligible impact of educational transfers, which could probably be explained by the null variance of educational transfers among states. Investigation in this phenomenon would play an important note in policy decisions regarding the allocation of resources in upper secondary.

\section{CONCLUSIONS}

Preliminary evidence suggests that the burden of educational expenditures on poor households is high. This finding suggest that actions aimed at increasing the participation of poor children should comprise subsidies for secondary textbooks, scholarships for transports and schools materials to reduce the burden on other schooling costs (i.e., unforeseen expenditures).

At primary level, non-poor students in public school spend four times the amount that extreme poor students spend in education. While at the university level non-poor individuals spend 1.4 times as much as poor students. The public subsidy, compared to the average student expenditure, is 2.8 times for primary level, 2.3 for lower secondary, 2.2 for upper secondary and 5.2 for university.

The total cost (student expenditure plus government subsidy) per student in primary public school corresponds to about $35 \%$ of the private primary school cost. For students in lower and upper secondary it represents $43 \%$ and $53 \%$, respectively. On the other hand, the cost of tertiary level is $13 \%$ higher in public schools as compared to private 
Probability to attend private school is positively influenced by per capita household income, number of house rooms, household head education level, and area (urban=1).

All explanatory variables are significant in the process of computing the marginal willingness to pay for public education services except for gender. As one moved through the expenditures distribution, gender, number of children and the schooling of the household head, are not significant in explaining $M M W P u$ at the tails of this distribution. Yet, at the median of the distribution, these variables are relevant. The non-poor and urban students get the most of the "savings" or effect from the public provision of school services at the basic education level. Our results show that it is likely that a large share of the effect or "savings" in basic schooling are due to differences in the quality of education between private and public schools.

There is a strong positive relationship between educational expenditures and per capita household income. Then government should charge a fee to those in the upper tail of the income distribution especially considering that the wealthy individuals have both a high valuation for quality of schooling and are able to pay for the educational service

The analysis indicates that the age, schooling, sector of activity and income per capita of the household head, as well as government effort (transfers or supply of teachers) are all relevant variables in explaining the probability of enrollment in upper secondary level. Special attention should be given to both the household head income per capita and the government's effort in light of the large marginal effect it has on upper secondary enrollment, particularly on the poor. 
APPENDIX 1. ENROLLMENTS AND EXPENDITURES ON EDUCATION

Table 1. Enrollments by type of school, 1994

\begin{tabular}{lcccc}
\hline Education level & Public & Private & Others & Total \\
\hline Primary & $13,593,797$ & 895,913 & 40,689 & $14,530,399$ \\
Lower Secondary & $4,661,522$ & 388,806 & 12,004 & $5,062,332$ \\
Upper Secondary & $2,386,758$ & 778,587 & 49,385 & $3,214,730$ \\
Tertiary & $1,461,189$ & 530,754 & 1,503 & $1,993,446$ \\
\hline
\end{tabular}

Source: ENIGH 94

Table 2. Enrollments by type of school, 1996

\begin{tabular}{lcccc}
\hline & Public & Private & Others & Total \\
\hline Primary & $13,802,395$ & 768,748 & 1,746 & $14,572,889$ \\
Lower Secondary & $4,972,116$ & 326,229 & 4,153 & $5,302,498$ \\
Upper Secondary & $2,767,993$ & 875,129 & 15,782 & $3,658,904$ \\
Tertiary & $1,459,820$ & 580,962 & 7,680 & $2,048,462$ \\
\hline
\end{tabular}

Source: ENIGH 96

Table 3. Federal Expenditure (Thousands of 1996 constant pesos)

\begin{tabular}{lcc}
\hline & 1994 & 1996 \\
\hline Primary & $32,351,871$ & $33,328,323$ \\
Lower Secondary & $15,508,552$ & $13,394,898$ \\
Upper Secondary & $11,916,903$ & $10,884,850$ \\
Tertiary & $23,688,868$ & $21,651,986$ \\
\hline
\end{tabular}

Source: DGPPyP, SEP 
Table 4. Household Expenditure on Education by Poverty Status ${ }^{4 /}, 1996$

\begin{tabular}{|c|c|c|c|c|c|c|}
\hline \multirow[t]{2}{*}{ Type of school } & \multicolumn{3}{|c|}{ Expenditures per student } & \multirow[b]{2}{*}{ Total } & \multirow[b]{2}{*}{ Expenditures (\%) ${ }^{2 /}$} & \multirow{2}{*}{$\begin{array}{c}\text { Sample } \\
\text { size }^{3 /}\end{array}$} \\
\hline & $\begin{array}{c}\text { Fees/Unforeseen } \\
\text { expenses }\end{array}$ & Services & Materials $^{1 /}$ & & & \\
\hline \multicolumn{7}{|l|}{ Private schools } \\
\hline Extreme & 2063.7 & 29.8 & 842.4 & 2935.9 & 14.6 & 12 \\
\hline Moderate & 1959.9 & 111.7 & 539.4 & 2611.0 & 11.1 & 50 \\
\hline Non poor & 8216.8 & 632.7 & 2750.4 & 11599.9 & 16.7 & 499 \\
\hline Total & 7662.3 & 584.6 & 2560.1 & 10807.0 & 16.6 & 561 \\
\hline \multicolumn{7}{|l|}{ Public schools } \\
\hline Extreme & 147.0 & 5.3 & 304.4 & 114.2 & 6.3 & 2825 \\
\hline Moderate & 365.9 & 24.9 & 648.0 & 259.7 & 7.0 & 2511 \\
\hline Non poor & 876.6 & 113.8 & 1105.3 & 523.9 & 6.7 & 2544 \\
\hline Total & 432.9 & 43.5 & 652.6 & 282.3 & 6.7 & 7880 \\
\hline \multicolumn{7}{|l|}{ Urban schools } \\
\hline Extreme & 253.3 & 8.9 & 422.4 & 171.1 & 8.2 & 1186 \\
\hline Moderate & 432.1 & 29.8 & 702.2 & 291.0 & 7.6 & 1867 \\
\hline Non poor & 2454.3 & 227.6 & 1486.6 & 1042.1 & 10.5 & 2561 \\
\hline Total & 1245.4 & 108.6 & 970.2 & 581.0 & 9.7 & 5614 \\
\hline \multicolumn{7}{|l|}{ Rural schools } \\
\hline Extreme & 69.9 & 2.4 & 206.0 & 69.6 & 4.4 & 1651 \\
\hline Moderate & 213.2 & 10.8 & 412.9 & 159.2 & 4.9 & 694 \\
\hline Non poor & 417.7 & 58.2 & 724.9 & 300.2 & 4.5 & 482 \\
\hline Total & 139.2 & 10.3 & 307.9 & 114.3 & 4.6 & 2827 \\
\hline
\end{tabular}

\footnotetext{
Source: ENIGH 96

1/ Textbooks, stationery, etc.

2/ As percentage of household's expenditures

3/ Number of households

4/ Annual pesos per student
}

Table 5. Household Expenditure on Education by Poverty Status, 1996

\begin{tabular}{lcccc|ccc}
\hline Poverty Status & $\begin{array}{c}\text { Expenditures per student (\%) } \\
\text { Fees/Unforesee } \\
\text { n expenses }\end{array}$ & Services & Materials & Total & $\begin{array}{c}\text { Educational } \\
\text { Expenditures } \\
(\%)^{2 \prime}\end{array}$ & $\begin{array}{c}\text { Services, Materials } \\
\text { Expenditures } \\
(\%)^{2 \prime}\end{array}$ & $\begin{array}{c}\text { Number of } \\
\text { Households }\end{array}$ \\
\hline Urban schools & & & & & & & \\
Extreme & 37.0 & 1.3 & 61.7 & 100.0 & 8.2 & 5.1 & 1186 \\
Moderate & 37.1 & 2.6 & 60.3 & 100.0 & 7.6 & 4.8 & 1867 \\
Non poor & 58.9 & 5.5 & 35.7 & 100.0 & 10.5 & 4.3 & 2561 \\
Total & 53.6 & 4.7 & 41.7 & 100.0 & 9.7 & 4.5 & 5614 \\
Rural schools & & & & & & & \\
Extreme & 25.1 & 0.8 & 74.0 & 100.0 & 4.4 & 3.3 & 1651 \\
Moderate & 33.5 & 1.7 & 64.8 & 100.0 & 4.9 & 3.2 & 694 \\
Non poor & 34.8 & 4.8 & 60.4 & 100.0 & 4.5 & 2.9 & 482 \\
Total & 30.4 & 2.3 & 67.3 & 100.0 & 4.6 & 3.2 & 2827 \\
\hline
\end{tabular}

Source: ENIGH 96

1/ Textbooks, stationary, etc.

2/ As percentage of household's expenditures 


\subsection{MARGINAL WILLIGNESS TO PAY METHODOLOGY ${ }^{17}$}

Step 1. Estimate the selection equation, using probit to analyze the factors determining household choice between public and private school for child $i$ :

(1) $Y i=Y(X i, Z i)$

where $\quad Y i=1$ if child $i$ is in private school; 0 if public

$X i=\mathrm{a}$ vector of independent variables such as father's income, parent's education, household assets, location, age and sex of child, etc.

$Z i=$ a trigger variable (to identify the whole model) that appears in this selection equation but not in the willingness to pay equation (see below).

One can develop an underlying household utility maximization model to generate the above specification.

Step 2. Estimate the household's willingness to pay for private education $(P v)$ of child $i$, e.g.

(2) $P i=P v(X i, M i, U i)$

where $\quad P i=$ household willingness to pay for private education of child $i$

$M i=$ mill's ratio calculated from the above probit equation

$U i=$ error term with mean value zero

Step 3. Estimate the household's willingness to pay for public education $(\mathrm{Pu})$ of child $i$, e.g.

(3) $P i=P u(X i, M i, U i)$

The following counterfactual exercise could then be done. Consider an average child with mean values of $X i=x i$ and $M i=m i$. What would his household be willing to spend for his private education?

Step 4. Using eq. 2 and plugging the mean value of $X i$ and $M i$, the willingness to pay $P i$ for private education could be estimated. Denote estimate as MeanPVi .This is different from the actual observed mean $P v$, which is the average for the self-selected sample of private school children.

Similarly, one could ask of such an average child: What would his household be willing to spend for public education? To answer this question:

\footnotetext{
${ }^{17}$ Vicente Paqueo and Lopez-Acevedo (1999). Methodological Note, mimeo.
} 
Step 5. Using eq. 3 and plugging the mean value of $X i$ and $M i$, we get an estimate of the amount of money the household would be willing to pay for the child's public education. Denote estimate as MeanPUi. Again this will be different from the observed average education spending of households for children in public schools, which would reflect the behavior of a self-selected sample of users of public education.

Step 6. Take the difference between MeanPVi and MeanPUi to measure the effect of the government provision of public schools on the education spending behavior of an average household.

Note that this difference would reflect the relative quality and payments (fees and contributions) associated with public and private schools. We can calculate this effect for various income groups by plugging their respective mean values for $X i$ and $M i$ into eqs. $1-3$.

A key question in this type of analysis is the availability of the trigger variable ( $Z i)$ to identify the model, which can be the provincial average learning achievement score of public schools relative to that of private schools, as index of the relative quality of these two types of schools.

\subsection{TABLES}

Table 1. Household Expenditures on Educational Service

Public Service

\begin{tabular}{lccc}
\hline Explanatories variables & Coef. & Mean & M.W. to P. \\
\hline Log Nat per capita H income & $0.76^{*}$ & 7.21 & 5.46 \\
Years of Schooling of HH & $0.01 *$ & 5.91 & 0.05 \\
Region (rural) & $0.66 *$ & 0.77 & 0.50 \\
Age & $0.12 *$ & 11.12 & 1.30 \\
Squared Age & $0.00 *$ & 143.74 & -0.35 \\
Gender (female) & -0.04 & 0.53 & -0.02 \\
Number of rooms & $0.09 *$ & 2.91 & 0.27 \\
Floor (not finished floor) & $0.22 *$ & 0.27 & 0.06 \\
Sewage (not sewage) & $0.26 *$ & 0.66 & 0.17 \\
Number of Children & $-0.12 *$ & 2.35 & -0.29 \\
Mill's Ratio & $0.45 *$ & 2.47 & 1.12 \\
Constant & $-2.67 *$ & & -2.67 \\
\hline Dependent Variable: & & & \\
Log Nat Expenditure & & 5.60 & 5.60 \\
Evaluated in pesos & & 270.64 & 270.23 \\
$\mathrm{R}^{2}$ & 0.42 & & \\
\hline
\end{tabular}

Source: Own calculations based on ENIGH 96 and DGPyP, SEP

* Significant at $5 \%$, ** Significant at $10 \%$

Italics: Reference category

\begin{tabular}{lccc} 
Private Service & \multicolumn{3}{l}{} \\
\hline Explanatories variables & Coef. & Mean & M.W. to P. \\
\hline Log Nat per capita H income & $0.57 *$ & 8.30 & 4.69 \\
Years of Schooling of HH & $0.02 *$ & 10.11 & 0.19 \\
Region (rural) & 0.06 & 0.97 & 0.06 \\
Age & 0.02 & 13.62 & 0.32 \\
Squared Age & 0.00 & 222.68 & -0.13 \\
Gender (female) & 0.05 & 0.46 & 0.02 \\
Number of rooms & -0.02 & 4.16 & -0.08 \\
Floor (not finished floor) & 0.02 & 0.71 & 0.01 \\
Sewage (not sewage) & $0.48 *$ & 0.94 & 0.45 \\
Number of Children & -0.02 & 2.00 & -0.04 \\
Mill's Ratio & -0.01 & 0.87 & -0.01 \\
Constant & $1.87 *$ & & 1.87 \\
\hline Dependent Variable: & & & \\
Log Nat Expenditure & & 7.32 & 7.36 \\
Evaluated in pesos & & 1506.59 & 1568.72 \\
$\mathrm{R}^{2}$ & 0.35 & & \\
\hline
\end{tabular}


Table 2. Household Expenditure on Educational Public Service by Area

\begin{tabular}{|c|c|c|c|c|c|c|}
\hline \multirow[b]{2}{*}{ Explanatories variables } & \multicolumn{3}{|c|}{ Urban } & \multicolumn{3}{|c|}{ Rural } \\
\hline & Coef. & Mean & M.W. to P. & Coef. & Mean & M.W. to P. \\
\hline Log Nat per capita income & $0.65 *$ & 7.4 & 4.84 & $0.97 *$ & 6.6 & 6.38 \\
\hline Years of Schooling of $\mathrm{HH}$ & $0.02 *$ & 6.7 & 0.12 & -0.02 & 3.2 & -0.06 \\
\hline Age & $0.11^{*}$ & 11.4 & 1.30 & $0.09 *$ & 10.2 & 0.94 \\
\hline Squared Age & $0.00^{*}$ & 151.3 & -0.35 & 0.00 & 119.0 & -0.10 \\
\hline Gender (female) & -0.02 & 0.5 & -0.01 & -0.09 & 0.5 & -0.04 \\
\hline Number of rooms & $0.08 *$ & 3.1 & 0.24 & $0.18 *$ & 2.2 & 0.39 \\
\hline Floor (not finished floor) & $0.29 *$ & 0.3 & 0.10 & -0.05 & 0.1 & 0.00 \\
\hline Sewage (not sewage) & $0.25 *$ & 0.8 & 0.20 & $0.26 *$ & 0.2 & 0.04 \\
\hline Number of Children & $-0.09 *$ & 2.3 & -0.20 & $-0.21 *$ & 2.5 & -0.52 \\
\hline Mill's Ratio & $0.47 *$ & 2.2 & 1.04 & $0.38 *$ & 3.3 & 1.25 \\
\hline Constant & $-1.39 *$ & & -1.39 & $-3.60 *$ & & -3.60 \\
\hline \multicolumn{7}{|l|}{ Dependent Variable: } \\
\hline Log Nat Expenditure & & 5.9 & 5.88 & & 4.7 & 4.68 \\
\hline Evaluated in pesos & & 359.70 & 359.57 & & 106.90 & 107.31 \\
\hline
\end{tabular}

Source: Own calculations based on ENIGH 96 and DGPyP, SEP

* Significant at $5 \%$, ** Significant at $10 \%$

Table 3. Household Expenditure on Educational Private Service by Area

\begin{tabular}{|c|c|c|c|c|c|c|c|}
\hline \multirow[b]{2}{*}{ Explanatories variables } & \multicolumn{3}{|c|}{ Urban } & \multicolumn{4}{|c|}{ Rural } \\
\hline & Coef. & Mean & M.W. to P. & Coef. & & Mean & M.W. to P. \\
\hline Log Nat per capita income & $0.58 *$ & 8.3 & 4.81 & $0 . \overline{42}$ & * & 7.34943 & 3.065 \\
\hline Years of Schooling of $\mathrm{HH}$ & $0.02 *$ & 10.3 & 0.20 & 0.01 & & 4.92671 & 0.050 \\
\hline Age & 0.02 & 13.5 & 0.33 & 0.19 & $* *$ & 17.2694 & 3.366 \\
\hline Squared Age & 0.00 & 219.3 & -0.13 & 0.00 & & 319.836 & -1.303 \\
\hline Gender (female) & 0.06 & 0.5 & 0.03 & -0.40 & $*$ & 0.41872 & -0.166 \\
\hline Number of rooms & -0.02 & 4.2 & -0.10 & -0.04 & & 3.10346 & -0.123 \\
\hline Floor (not finished floor) & 0.04 & 0.7 & 0.03 & -0.51 & $*$ & 0.22027 & -0.113 \\
\hline Sewage (not sewage) & $0.62 *$ & 1.0 & 0.59 & 0.46 & & 0.41467 & 0.190 \\
\hline Number of Children & -0.03 & 2.0 & -0.05 & -0.16 & & 2.53821 & -0.394 \\
\hline Mill's Ratio & 0.01 & 0.8 & 0.01 & 0.15 & & 1.94875 & 0.300 \\
\hline Constant & $1.68 *$ & & 1.68 & 1.63 & & & 1.634 \\
\hline \multicolumn{8}{|l|}{ Dependent Variable } \\
\hline Log Nat Expenditure & & 7.3 & 7.39 & & & 6.54069 & 6.50 \\
\hline Evaluated in pesos & & 1548.0 & 1614.7 & & & 692.8 & 668.4 \\
\hline
\end{tabular}

Source: Own calculations based on ENIGH 96 and DGPyP, SEP

* Significant at $5 \%$, ** Significant at $10 \%$

Table 4. Household Expenditure on Educational Public Service by Povery Status

\begin{tabular}{|c|c|c|c|c|c|c|c|c|c|}
\hline \multirow[b]{2}{*}{ Explanatory variables } & \multirow[b]{2}{*}{ Coef. } & \multicolumn{2}{|c|}{ Exteme } & \multicolumn{3}{|c|}{ Moderate } & \multicolumn{3}{|c|}{ No Poor } \\
\hline & & Mean & M.W. to $\mathbf{P}$. & Coef. & Mean & M.W. to P. & Coef. & Mean & M.W. to P. \\
\hline Log Nat per capita income & $0.64 *$ & 6.49 & 4.14 & $0.47 *$ & 7.22 & 3.41 & $0.84^{*}$ & 7.42 & 6.25 \\
\hline Years of Schooling of $\mathrm{HH}$ & $0.03 *$ & 4.39 & 0.15 & $0.02 *$ & 6.02 & 0.14 & 0.00 & 6.30 & -0.02 \\
\hline Region (rural) & Dropped & 1.00 & 0.00 & dropped & 1.00 & 0.00 & $0.47 *$ & 0.56 & 0.27 \\
\hline Age & $0.10 *$ & 10.45 & 1.06 & $0.14 *$ & 11.08 & 1.53 & $0.10 *$ & 11.34 & 1.17 \\
\hline Squared Age & 0.00 & 121.76 & -0.14 & $0.00 *$ & 138.78 & -0.41 & $0.00 *$ & 153.21 & -0.34 \\
\hline Gender & -0.08 & 0.54 & -0.04 & -0.01 & 0.54 & -0.01 & -0.04 & 0.51 & -0.02 \\
\hline Number of rooms & 0.02 & 2.43 & 0.06 & $0.11 *$ & 2.90 & 0.33 & $0.11 *$ & 3.07 & 0.35 \\
\hline Floor (not finished floor) & -0.03 & 0.11 & 0.00 & $0.29 *$ & 0.26 & 0.07 & $0.24 *$ & 0.33 & 0.08 \\
\hline Sewage (not sewage) & $0.45 *$ & 0.60 & 0.27 & 0.06 & 0.79 & 0.05 & $0.33 *$ & 0.60 & 0.19 \\
\hline Number of Children & $-0.12 *$ & 2.71 & -0.33 & $-0.07^{*}$ & 2.27 & -0.16 & $-0.15 *$ & 2.29 & -0.34 \\
\hline Mill's Ratio & $0.48 *$ & 3.01 & 1.45 & $0.43^{*}$ & 2.39 & 1.03 & $0.43 *$ & 2.36 & 1.02 \\
\hline Constant & -1.26 & & -1.26 & -0.25 & & -0.25 & $-3.02 *$ & & -3.02 \\
\hline \multicolumn{10}{|l|}{ Dependent Variable } \\
\hline Log Nat Expenditure & & 5.36 & 5.36 & & 5.74 & 5.74 & & 5.60 & 5.59 \\
\hline Evaluated in pesos & & 212.79 & 212.31 & & 310.30 & 310.06 & & 269.12 & 268.50 \\
\hline
\end{tabular}

Source: Own calculations based on ENIGH 96 and DGPyP, SEP

* Significant at 5\%, ** Significant at $10 \%$ 
Table 5. Household Expenditure on Educational Private Service by Povery Status

\begin{tabular}{|c|c|c|c|c|c|c|c|c|c|}
\hline \multirow[b]{2}{*}{ Explanatory variables } & \multirow[b]{2}{*}{ Coef. } & \multicolumn{2}{|c|}{ Exteme } & \multicolumn{3}{|c|}{ Moderate } & \multicolumn{3}{|c|}{ No Poor } \\
\hline & & Mean & M.W. to P. & Coef. & Mean & M.W. to P. & Coef. & Mean & M.W. to P. \\
\hline Log Nat per capita income & -1.14 & 6.55 & -7.43 & 0.43 & 7.30 & 3.12 & $0.59 *$ & 8.52 & 5.02 \\
\hline Years of Schooling of $\mathrm{HH}$ & $0.22 * *$ & 5.40 & 1.20 & $-0.06 * *$ & 5.63 & -0.32 & $0.02 *$ & 10.96 & 0.19 \\
\hline Region (rural) & Dropped & 1.00 & 0.00 & Dropped & 1.00 & 0.00 & -0.09 & 0.96 & -0.08 \\
\hline Age & $1.25^{* *}$ & 14.61 & 18.21 & $0.13 *$ & 16.47 & 2.15 & 0.01 & 13.17 & 0.19 \\
\hline Squared Age & $-0.05 *$ & 230.96 & -12.11 & $0.00^{*}$ & 305.14 & -1.18 & 0.00 & 210.31 & -0.06 \\
\hline Gender & 0.43 & 0.25 & 0.11 & 0.02 & 0.43 & 0.01 & 0.05 & 0.48 & 0.03 \\
\hline Number of rooms & 0.76 & 3.08 & 2.33 & 0.07 & 2.97 & 0.21 & -0.02 & 4.38 & -0.09 \\
\hline Floor (not finished floor) & $-1.57 * *$ & 0.49 & -0.77 & $-0.37 *$ & 0.36 & -0.14 & 0.06 & 0.77 & 0.05 \\
\hline Sewage (not sewage) & 1.29 & 0.86 & 1.11 & $0.45 * *$ & 0.80 & 0.36 & $0.71^{*}$ & 0.96 & 0.68 \\
\hline Number of Children & -0.64 & 2.09 & -1.33 & $-0.20 *$ & 1.95 & -0.39 & 0.00 & 2.00 & -0.01 \\
\hline Mill's Ratio & -0.57 & 2.18 & -1.24 & -0.20 & 1.39 & -0.27 & -0.02 & 0.77 & -0.02 \\
\hline Constant & 6.19 & & 6.19 & 3.05 & & 3.05 & $1.62 *$ & & 1.62 \\
\hline \multicolumn{10}{|l|}{ Dependent Variable } \\
\hline Log Nat Expenditure & & 6.61 & 6.27 & & 6.59 & 6.61 & & 7.45 & 7.50 \\
\hline Evaluated in pesos & & 745.90 & 528.66 & & 726.01 & 740.81 & & 1725.7 & 1807.44 \\
\hline
\end{tabular}

Source: Own calculations based on ENIGH 96 and DGPyP, SEP

* Significant at 5\%, ** Significant at $10 \%$

Table 6. Household Expenditure on Educational Public Service by Type of Education

\begin{tabular}{|c|c|c|c|c|c|c|c|c|c|c|c|c|c|c|c|}
\hline \multirow[b]{2}{*}{ Explanatory variables } & \multicolumn{3}{|c|}{ Pre Primary } & \multicolumn{3}{|c|}{ Primary } & \multicolumn{3}{|c|}{ Lower Secondary } & \multicolumn{3}{|c|}{ Upper Secondary } & \multicolumn{3}{|c|}{ Technical Education } \\
\hline & Coef. & Mean & M.W. to P. & Coef. & Mean & M.W. to P. & Coef. & Mean & M.W. to $P$. & Coef. & Mean & M.W. to P. & Coef. & Mean & M.W. to $P$. \\
\hline Log Nat per capita income & 0.83 & 7.20 & 5.98 & 0.79 & 7.05 & $5.5 \overline{3}$ & 0.50 & 7.33 & 3.63 & 0.18 & 7.63 & 1.36 & 0.50 & 7.56 & 3.78 \\
\hline Years of Schooling of $\mathrm{HH}$ & 0.02 & 6.14 & 0.10 & 0.01 & 5.40 & 0.07 & -0.01 & 6.17 & -0.03 & -0.01 & 7.47 & -0.06 & -0.01 & 6.12 & -0.09 \\
\hline Region (rural) & 0.71 & 0.66 & 0.47 & 0.64 & 0.71 & 0.45 & 0.55 & 0.83 & 0.45 & 0.05 & 0.89 & 0.05 & -0.30 & 0.92 & -0.28 \\
\hline Age & -1.29 & 4.99 & -6.45 & 0.07 & 8.91 & 0.62 & -0.05 & 13.56 & -0.66 & -0.09 & 17.26 & -1.49 & -0.07 & 20.03 & -1.49 \\
\hline Squared Age & 0.13 & 24.93 & 3.19 & 0.00 & 84.08 & -0.16 & 0.00 & 187.34 & -0.03 & 0.00 & 311.73 & 0.22 & 0.00 & 449.99 & 0.46 \\
\hline Gender (female) & 0.08 & 0.53 & 0.04 & -0.09 & 0.52 & -0.04 & -0.01 & 0.53 & -0.01 & 0.12 & 0.59 & 0.07 & 0.39 & 0.38 & 0.15 \\
\hline Number of rooms & 0.09 & 2.68 & 0.24 & 0.08 & 2.62 & 0.22 & 0.07 & 3.20 & 0.22 & 0.02 & 3.65 & 0.08 & 0.11 & 3.47 & 0.39 \\
\hline Floor (not floor finished) & 0.19 & 0.22 & 0.04 & 0.09 & 0.23 & 0.02 & 0.38 & 0.32 & 0.12 & 0.15 & 0.39 & 0.06 & -0.07 & 0.35 & -0.03 \\
\hline Sewage (not sewage) & 0.22 & 0.58 & 0.13 & 0.31 & 0.58 & 0.18 & 0.15 & 0.73 & 0.11 & -0.04 & 0.83 & -0.04 & -0.45 & 0.82 & -0.37 \\
\hline Num. Children & -0.04 & 1.96 & -0.08 & -0.10 & 2.45 & -0.25 & -0.14 & 2.38 & -0.33 & 0.02 & 2.19 & 0.05 & 0.03 & 1.87 & 0.06 \\
\hline Mills Ratio & 0.58 & 2.59 & 1.51 & 0.39 & 2.56 & 0.99 & 0.26 & 2.44 & 0.64 & -0.05 & 2.22 & -0.11 & 0.03 & 1.75 & 0.06 \\
\hline $\begin{array}{l}\text { Constant } \\
\text { Dependent Variable }\end{array}$ & 0.22 & & 0.22 & -2.45 & & -2.45 & 1.95 & & 1.95 & 6.27 & & 6.27 & 3.81 & & 3.81 \\
\hline $\begin{array}{l}\text { Log Nat Expenditure } \\
\text { Evaluated in pesos }\end{array}$ & & $\begin{array}{c}5.39 \\
220.09\end{array}$ & $\begin{array}{c}5.39 \\
220.09\end{array}$ & & $\begin{array}{c}5.19 \\
178.67\end{array}$ & $\begin{array}{c}5.19 \\
178.67\end{array}$ & & $\begin{array}{c}6.07 \\
431.42\end{array}$ & $\begin{array}{c}6.07 \\
431.42\end{array}$ & & $\begin{array}{c}6.46 \\
636.77\end{array}$ & $\begin{array}{c}6.45 \\
635.49\end{array}$ & & $\begin{array}{c}6.39 \\
596.92\end{array}$ & $\begin{array}{c}6.45 \\
634.80\end{array}$ \\
\hline
\end{tabular}

Source: Own calculations based on ENIGH 96 and DGPyP, SEP

* Figures in bold are significant at $5 \%$

Table 7. Household Expenditure on Educational Private Service by Type of Education

\begin{tabular}{|c|c|c|c|c|c|c|c|c|c|c|c|c|c|c|c|}
\hline \multirow[b]{2}{*}{ Explanatory va riables } & \multicolumn{3}{|c|}{ Pre Primary } & \multirow{2}{*}{\multicolumn{3}{|c|}{ Primary }} & \multicolumn{3}{|c|}{ Lower Secondary } & \multicolumn{3}{|c|}{ Upper Secondary } & \multicolumn{3}{|c|}{ Technical Education } \\
\hline & Coef. & Mean & M.W. to $P$. & & Mean & M.W. to P. & Coef. & Mean & M.W. to $P$. & Coef. & & M.W. to $P$. & Coef. & & M.W. to P. \\
\hline Log Nat per capita income & 0.81 & 8.36 & 6.79 & 0.39 & 8.54 & 3.30 & 0.67 & 8.43 & 5.67 & 0.45 & 8,32 & 3.71 & 0.33 & 7.69 & 2.53 \\
\hline Years of Schooling of $\mathrm{HH}$ & -0.03 & 12.24 & -0.40 & 0.02 & 11.99 & 0.22 & -0.01 & 10.37 & -0.06 & 0.03 & 9.54 & 0.28 & 0.01 & 6.47 & 0.10 \\
\hline Region (nural) & 1.41 & 0.98 & 1.38 & $\mathrm{D}$ & 1.00 & 0.00 & -0.16 & 0.97 & -0.15 & 0.15 & 0.95 & 0.14 & -0.16 & 0.93 & -0.15 \\
\hline Age & D & 5.00 & 0.00 & 0.18 & 8.47 & 1.53 & -0.09 & 14.07 & -1.27 & -0.17 & 17.39 & -2.94 & -0.14 & 20.41 & -2.85 \\
\hline Squared Age & D & 25.00 & 0.00 & -0.01 & 74.86 & -0.80 & 0.00 & 207.27 & 0.10 & 0.00 & 309.31 & 0.80 & 0.00 & 452.93 & 1.16 \\
\hline Gender (female) & 0.01 & 0.52 & 0.00 & 0.08 & 0.48 & 0.04 & 0.02 & 0.47 & 0.01 & 0.17 & 0.49 & 0.08 & 0.17 & 0.35 & 0.06 \\
\hline Number of rooms & 0.16 & 3.66 & 0.58 & -0.06 & 4.41 & -0.29 & -0.04 & 4.37 & -0.17 & -0.05 & 4.38 & -0.20 & 0.01 & 3.41 & 0.05 \\
\hline Floor (not floor finished) & 0.17 & 0.71 & 0.12 & -0.01 & 0.80 & -0.01 & -0.25 & 0.81 & -0.20 & 0.00 & 0.75 & 0.00 & 0.02 & 0.40 & 0.01 \\
\hline Sewage (not sewage) & 1.06 & 0.91 & 0.97 & 1.30 & 0.98 & 1.28 & 0.44 & 0.95 & 0.42 & 0.44 & 0.93 & 0.41 & 0.08 & 0.85 & 0.06 \\
\hline Num. Children & 0.25 & 1.63 & 0.42 & 0.00 & 2.04 & 0.00 & 0.00 & 2.10 & 0.00 & 0.04 & 1.94 & 0.09 & -0.11 & 2.08 & -0.23 \\
\hline Mills Ratio & 0.37 & 0.94 & 0.34 & -0.32 & 0.96 & -0.31 & -0.03 & 0.94 & -0.03 & -0.19 & 0.76 & -0.14 & 0.40 & 0.77 & 0.31 \\
\hline Constant & -2.92 & & -2.92 & 2.51 & & 2.51 & 3.29 & & 3.29 & 5.27 & & 5.27 & 5.77 & & 5.77 \\
\hline Dependent Variable & & & & & & & & & & & & & & & \\
\hline Log Nat Expenditure & & 7.21 & 7.29 & & 7.44 & 7.46 & & 7.50 & 7.60 & & 7.48 & 7.49 & & 6.74 & 6.83 \\
\hline Evaluated in pesos & & 1353.7 & 1464.03 & & 1699.5 & 1730.00 & & 1814.2 & 2006.22 & & 1776.6 & 1789.22 & & 843.65 & 922.02 \\
\hline
\end{tabular}

Source: Own calculations based on ENIGH 96 and DGPyP, SEP

* Figures in bold are significant at $5 \%$

$\mathrm{D}=$ variable dropped 
Table 8. Quantile Analysis of Household Expenditure on Educational Public Service

\begin{tabular}{|c|c|c|c|c|c|c|c|c|c|}
\hline \multirow[b]{2}{*}{ Explanatories variables } & \multicolumn{3}{|c|}{ Quantile regression 0.01} & \multicolumn{3}{|c|}{ Quantile regression 0.50} & \multicolumn{3}{|c|}{ Quantile regression 0.90} \\
\hline & Coef. & Q 0.10 & M.W. to P. & Coef. & Q 0.50 & M.W. to P. & Coef. & $Q 0.90$ & M.W. to P. \\
\hline Log Nat per capita $\mathrm{H}$ income & $0.82 *$ & 6.27 & 5.11 & $0.72 *$ & 7.22 & 5.22 & $0.51^{*}$ & 8.17 & 4.14 \\
\hline Years of Schooling of $\mathrm{HH}$ & 0.00 & 0.00 & 0.00 & $0.01 *$ & 6.00 & 0.08 & $0.02 *$ & 12.00 & 0.24 \\
\hline Region (rural) & $0.80 *$ & 0.00 & 0.00 & $0.64 *$ & 1.00 & 0.64 & $0.37 *$ & 1.00 & 0.37 \\
\hline Age & $0.16 *$ & 6.00 & 0.98 & $0.13 *$ & 11,00 & 1.44 & $0.12 *$ & 16.00 & 1.92 \\
\hline Squared Age & $0.00^{*}$ & 36.00 & -0.13 & $0.00 *$ & 121.00 & -0.31 & $0.00 *$ & 256.00 & -0.58 \\
\hline Gender (female) & 0.05 & 0.00 & 0.00 & $-0.06 *$ & 1.00 & -0.06 & 0.02 & 1.00 & 0.02 \\
\hline Number of rooms & $0.06 *$ & 1.00 & 0.06 & $0.09 *$ & 3.00 & 0.28 & $0.07^{*}$ & 5.00 & 0.33 \\
\hline Floor (not finished floor) & $0.43 *$ & 0.00 & 0.00 & $0.21 *$ & 0.00 & 0.00 & $0.13 *$ & 1.00 & 0.13 \\
\hline Sewage (not sewage) & $0.42 *$ & 0.00 & 0.00 & $0.22 *$ & 1.00 & 0.22 & $0.14^{*}$ & 1.00 & 0.14 \\
\hline Number of Children & -0.02 & 1.00 & -0.02 & $-0.11 *$ & 2.00 & -0.23 & $-0.11 *$ & 4.00 & -0.44 \\
\hline Mill's Ratio & $0.59 *$ & 1.30 & 0.77 & $0.41 *$ & 2.45 & 1.01 & $0.22 *$ & 3.68 & 0.81 \\
\hline Constant & $-5.35 *$ & & -5.35 & $-2.28 *$ & & -2.28 & $1.00 *$ & & 1.00 \\
\hline Dependent Variable & & & & & & & & & \\
\hline Log Nat Expenditure & & 4.01 & 1.42 & & 5.79 & 6.01 & & 6.98 & 8.08 \\
\hline Evaluated in pesos & & 54.91 & 4.13 & & 326.44 & 409.05 & & 1075.65 & 3224.26 \\
\hline
\end{tabular}

Source: Own calculations based on ENIGH 96 and DGPyP, SEP

* Significant at $5 \%, * *$ Significant at $10 \%$

Table 9. Quantile Analysis of Household Expenditure on Educational Private Service

\begin{tabular}{|c|c|c|c|c|c|c|c|c|c|}
\hline \multirow[b]{2}{*}{ Explanatories variables } & \multicolumn{3}{|c|}{ Quantile regression 0.01} & \multicolumn{3}{|c|}{ Quantile regression 0.50} & \multicolumn{3}{|c|}{ Quantile regression 0.90} \\
\hline & Coef. & Q0.10 & M.W, to P. & Coef. & $Q 0.50$ & M.W. to P. & Coef. & $\mathbf{Q} 0.90$ & M.W. to P. \\
\hline Log Nat per capita $\mathrm{H}$ income & $0.50^{*}$ & 7.24 & 3.64 & 0.53 * & 8.30 & 4.39 & $0 . \overline{2 *}$ & 9.40 & 6.79 \\
\hline Years of Schooling of HH & $0.04 *$ & 3.00 & 0.13 & $0.03 *$ & 9.00 & 0.25 & 0.00 & 16.50 & 0.00 \\
\hline Region (rural) & -0.27 & 1.00 & -0.27 & -0.18 & 1.00 & -0.18 & 0.35 & 1.00 & 0.35 \\
\hline Age & $0.10^{*}$ & 6.00 & 0.58 & $0.03 *$ & 14.00 & 0.44 & 0.00 & 20.00 & 0.08 \\
\hline Squared Age & $0.00 *$ & 36.00 & -0.11 & $0.00 *$ & 196.00 & -0.17 & 0.00 & 400.00 & 0.02 \\
\hline Gender (female) & -0.10 & 0.00 & 0.00 & 0.08 & 0.00 & 0.00 & 0.10 & 1.00 & 0.10 \\
\hline Number of rooms & -0.04 & 2.00 & -0.08 & 0.03 & 4.00 & 0.10 & 0.01 & 6.00 & 0.06 \\
\hline Floor (not finished floor) & -0.12 & 0.00 & 0.00 & 0.03 & 1.00 & 0.03 & 0.15 & 1.00 & 0.15 \\
\hline Sewage (not sewage) & $0.71 *$ & 1.00 & 0.71 & $0.39 *$ & 1.00 & 0.39 & -0.16 & 1.00 & -0.16 \\
\hline Number of Children & 0.09 & 1.00 & 0.09 & -0.06 & 2.00 & -0.11 & -0.02 & 3.00 & -0.06 \\
\hline Mill's Ratio & -0.06 & 0.17 & -0.01 & 0.06 & 0.75 & 0.05 & -0.03 & 1.71 & -0.06 \\
\hline Constant & 0.94 & & 0.94 & $2.09 *$ & & 2.09 & $1.93 *$ & & 1.93 \\
\hline Dependent Variable & & & & & & & & & \\
\hline Log Nat Expenditure & & 6.13 & 5.62 & & 7.31 & 7.28 & & 8.61 & 9.20 \\
\hline Evaluated in pesos & & 460.01 & 275.37 & & 1497.22 & 1445.25 & & 5490.24 & 9883.40 \\
\hline
\end{tabular}

Source: Own calculations based on ENIGH 96 and DGPyP, SEP

* Significant at $5 \%, * *$ Significant at $10 \%$ 
This kind of regression model has some desirable characteristics, especially when one is interested in the analysis of certain variable throughout its distribution. The main features of the quantile regression models can be summarized as follows:

i) The model can be used to characterize the entire conditional distribution of the dependent variable;

ii) The quantile regression objective function is a weighted sum of absolute deviations, which gives a robust measure of location, so that the estimated coefficient vector is non sensitive to outlier observations of dependent variable;

iii) When the error term is non-normal, quantile regression estimators may be more efficient than least squares estimators; and,

iv) Different solutions at distinct quantiles may be interpreted as differences in the responses of the dependent variable to changes in the independent variables at various points in the conditional distribution of the dependent variable [see Buchinsky (1998)].

Assume that earnings, or other monetary variable, $\left(Y_{i}\right)$ depends on a set of independent variables $X_{i}$, such as that function can be written as a quantile regression. Then, we have

$$
\log Y_{i}=X_{i} \beta_{\theta}+\mu_{\theta}
$$

$$
\text { with Quant }{ }_{\theta}\left(\log Y_{i} \mid X_{i}\right)=X_{i} \beta_{\theta} \quad(i=1, \ldots, \mathrm{n})
$$

Where $\beta_{\theta}$ and $X_{i}$ are $K \mathrm{x} 1$ vectors, and $X_{i I} \equiv 1$;

Quant ${ }_{\theta}(\log Y \mid X)$ denotes the $\theta$ th conditional quantile of $Y$ given $X$;

Also let $f_{\mu_{\theta}}(\cdot \mid X)$ denote the density of $\mu_{\theta}$ given $X$ [it follows that Quant $\left(\mu_{\theta} \mid X\right)=0$ ].

Note that the $X_{i}$ vector may include a set of explanatory dummy variables as well as some controls. For an extensive review see Buchinsky (1994). 
Table 1. Determinants of Upper Secondary School Enrollment

\begin{tabular}{|c|c|c|c|c|c|c|c|c|c|c|}
\hline \multirow[b]{2}{*}{ Variables } & \multicolumn{2}{|c|}{ Full Sample } & \multicolumn{2}{|c|}{ Poorest $40 \%$} & \multicolumn{2}{|c|}{ Richest $40 \%$} & \multicolumn{2}{|c|}{ Urban } & \multicolumn{2}{|c|}{ Rural } \\
\hline & $\begin{array}{c}\text { Marginal } \\
\text { Effect }\end{array}$ & $\begin{array}{l}\text { Level } \\
\text { Sign. }\end{array}$ & $\begin{array}{c}\text { Marginal } \\
\text { Effect }\end{array}$ & $\begin{array}{l}\text { Level } \\
\text { Sign. }\end{array}$ & $\begin{array}{c}\text { Marginal } \\
\text { Effect }\end{array}$ & $\begin{array}{l}\text { Level } \\
\text { sign. }\end{array}$ & $\begin{array}{c}\text { Marginal } \\
\text { effect }\end{array}$ & $\begin{array}{c}\text { Level } \\
\text { sign. }\end{array}$ & $\begin{array}{c}\text { Marginal } \\
\text { Effect }\end{array}$ & $\begin{array}{c}\text { Level } \\
\text { sign. }\end{array}$ \\
\hline \multicolumn{11}{|l|}{ Individuals Characteristics } \\
\hline Age & 0.78 & 0.02 & 1.58 & 0.01 & 0.08 & 0.85 & 0.43 & 0.21 & 1.44 & 0.04 \\
\hline Age Square & -0.03 & 0.01 & -0.05 & 0.00 & -0.01 & 0.67 & -0.02 & 0.12 & -0.05 & 0.03 \\
\hline Female Gender & -0.02 & 0.39 & -0.04 & 0.30 & -0.02 & 0.45 & -0.02 & 0.41 & 0.00 & 0.98 \\
\hline \multicolumn{11}{|c|}{ Head of Household (HH) Characteristics } \\
\hline HH Age & 0.02 & 0.00 & -0.01 & 0.40 & 0.03 & 0.00 & 0.02 & 0.00 & 0.02 & 0.08 \\
\hline HH Age square & 0.00 & 0.00 & 0.00 & 0.26 & 0.00 & 0.00 & 0.00 & 0.00 & 0.00 & 0.09 \\
\hline HH female gender & 0.06 & 0.05 & 0.06 & 0.32 & 0.06 & 0.09 & 0.02 & 0.52 & 0.24 & 0.00 \\
\hline HH Some Primary & -0.06 & 0.06 & -0.12 & 0.02 & 0.03 & 0.58 & -0.01 & 0.84 & -0.22 & 0.00 \\
\hline HH Primary complete & 0.05 & 0.14 & 0.01 & 0.90 & 0.10 & 0.03 & 0.05 & 0.14 & -0.04 & 0.58 \\
\hline HH L-Secondary complete & 0.16 & 0.00 & 0.10 & 0.19 & 0.15 & 0.00 & 0.14 & 0.00 & 0.03 & 0.77 \\
\hline HH U-Secondary or higher & 0.29 & 0.00 & 0.32 & 0.01 & 0.26 & 0.00 & 0.26 & 0.00 & 0.33 & 0.09 \\
\hline Agriculture/Mining & 0.04 & 0.61 & -0.28 & 0.06 & 0.14 & 0.09 & 0.08 & 0.30 & -0.17 & 0.38 \\
\hline Manufacturing & -0.12 & 0.00 & -0.14 & 0.04 & -0.08 & 0.10 & 0.04 & 0.44 & -0.13 & 0.10 \\
\hline Utilities & -0.03 & 0.41 & 0.01 & 0.90 & -0.01 & 0.88 & -0.01 & 0.71 & -0.14 & 0.18 \\
\hline Commerce & 0.00 & 0.92 & -0.12 & 0.08 & 0.08 & 0.12 & 0.03 & 0.54 & -0.08 & 0.44 \\
\hline Transports/Communications & 0.01 & 0.85 & 0.03 & 0.69 & 0.04 & 0.33 & 0.03 & 0.33 & -0.11 & 0.28 \\
\hline Financial Services & -0.01 & 0.83 & 0.02 & 0.83 & 0.06 & 0.21 & 0.00 & 0.97 & -0.05 & 0.75 \\
\hline Services & -0.03 & 0.78 & -0.33 & 0.22 & 0.09 & 0.45 & -0.02 & 0.89 & -0.09 & 0.79 \\
\hline Agricultural Worker & 0.03 & 0.53 & -0.02 & 0.80 & 0.17 & 0.02 & 0.05 & 0.50 & -0.09 & 0.29 \\
\hline Business Owner & 0.04 & 0.29 & 0.24 & 0.01 & -0.10 & 0.04 & 0.05 & 0.23 & 0.04 & 0.65 \\
\hline Self Employed & 0.03 & 0.69 & -0.22 & 0.17 & 0.14 & 0.08 & 0.05 & 0.55 & -0.02 & 0.92 \\
\hline Formal worker & 0.02 & 0.77 & -0.20 & 0.21 & 0.11 & 0.31 & 0.03 & 0.66 & -0.03 & 0.88 \\
\hline \multicolumn{11}{|l|}{ Dwelling Characteristics } \\
\hline Electrified & -0.03 & 0.60 & -0.01 & 0.95 & -0.11 & 0.34 & -0.13 & 0.10 & 0.08 & 0.38 \\
\hline Sewage & 0.07 & 0.00 & 0.08 & 0.05 & 0.12 & 0.01 & 0.05 & 0.08 & 0.08 & 0.13 \\
\hline \multicolumn{11}{|l|}{ Family Characteristics } \\
\hline Number of babies & -0.06 & 0.02 & -0.02 & 0.58 & -0.18 & 0.00 & -0.05 & 0.13 & -0.04 & 0.40 \\
\hline Number of babies square & 0.01 & 0.56 & -0.01 & 0.58 & 0.06 & 0.02 & 0.00 & 1.00 & 0.01 & 0.67 \\
\hline Number of children & 0.03 & 0.15 & 0.04 & 0.34 & 0.04 & 0.25 & 0.01 & 0.56 & 0.08 & 0.09 \\
\hline Number of children square & -0.01 & 0.03 & -0.01 & 0.10 & -0.01 & 0.31 & -0.01 & 0.17 & -0.02 & 0.05 \\
\hline Number of Adults & 0.01 & 0.73 & 0.06 & 0.41 & -0.01 & 0.75 & -0.01 & 0.86 & 0.08 & 0.39 \\
\hline Number of Adults square & 0.00 & 0.30 & -0.01 & 0.14 & 0.00 & 0.86 & 0.00 & 0.62 & -0.01 & 0.20 \\
\hline HH income per capita & 0.05 & 0.00 & & & & & 0.05 & 0.01 & 0.01 & 0.88 \\
\hline \multicolumn{11}{|l|}{ Government Effort } \\
\hline $\begin{array}{l}\text { Teachers per } 100015-19 \text { years } \\
\text { old population }\end{array}$ & 0.07 & 0.00 & 0.13 & 0.01 & 0.02 & 0.52 & 0.03 & 0.19 & 0.25 & 0.00 \\
\hline Federal Expenditure & 0.00 & 0.33 & 0.00 & 0.08 & 0.00 & 0.44 & 0.00 & 0.93 & 0.00 & 0.04 \\
\hline
\end{tabular}

Source: Own calculation based on ENIGH 96 


\section{REFERENCES}

Buchinsky, Moshe (1994), "Changes in the U.S. Wage Structure 1963-1987: Application of Quantile Regression”. Econometrica, vol. 62, num. 2, pp. 405-458.

Buchinsky, Moshe (1995), "Quantile Regression, Box-Cox transformation model and the U.S. wage structure, 1963-1987”. Journal of Econometrics, vol. 65, pp. 109-154.

Buchinsky, Moshe (1998), "Recent Advances in Quantile Regression Models: A Practical Guideline for Empirical Research". Journal of Human Resources, vol. 33, num. 1, pp.88-126.

Consejo Nacional de Población. Proyecciones de la Población de México 1996-2050. México: Diciembre 1998.

Diario Oficial de la Federación. Ley Federal de Educación. México: Secretaría de Gobernación 1993.

Londoño, Juan Luis (1996), "Poverty, Inequality and Human Capital Development in Latin America, 1950-2025". World Bank Latin American and Caribbean Studies, (June).

Montenegro, Claudio E. (1998), "The Structure of Wages in Chile 1960-1996: An Approach of Quantile Regression”. Estudios de Economia, vol. 25, num. 1, pp. 71-98.

Organización para la Cooperación y Desarrollo Económicos. Exámenes de las Políticas Nacionales de Educación: México. Educación Superior. Francia: OCDE, 1997.

Paqueo, Vicente and Lopez-Acevedo (1999), "Estimating the Effect of Government Spending on Household Education Expenditures Among Poor and Non Poor Children”. Mimeo.

Presidencia de la República. Cuarto Informe de Gobierno, $1^{\circ}$ de Septiembre, 1998. México: Septiembre 1998.

Psacharopoulos, G., Morley, S., Fiszbein, A., Lee, H., Wood, B. (1992), "Poverty and income distribution in Latin America: the story ot the 1980s". The World Bank.

Psacharopoulos, George (1993), "Returns to Investment in Education: A Global Update". World Bank Policy Research Paper No. 1067, (January).

Schultz, T. Paul (1988), "Education Investments and Returns", in H. Chenery and T.N. Srinivasan, editors, Handbook of Development Economics, vol. I, Elsevier Science Publishers B.V., pp. 543-629.

SEP. Dirección General de Planeación, Programación y Presupuesto. Compendio Estadístico por Entidad Federativa 1997. México: Noviembre 1997.

SEP. Subsecretaría de Educación e Investigación Tecnológicas. Estadística Básica. Sistema Nacional de Educación Tecnológica, 1997-1998, Inicio de Cursos. México: DGETI, 1998.

Secretaría de Educación Pública. Informe de Labores 1997-1998. México: Octubre 1998.

SEP. Dirección General de Planeación, Programación y Presupuesto. Estadística Básica de Educación Superior. Inicio de cursos 1997-1998. México: Enero 1999. 
Secretaría de Hacienda y Crédito Público. Plan Nacional de Desarrollo, Informe de Ejecución 1998. México: Marzo 1999.

Secretaría de Educación Pública. Programa del Sector Educativo para 1999. México: 1999.

Shultz, Paul T. and Germano Mwabu (1996), "Education Returns Across Quantile of the Wage Function: Alternative Explanations for Returns to Education by Race in South Africa". Yale Economic Growth Center Discussion Paper, num. 744, pp. 24.

Van de Walle, Dominique and Kimberly Nead (1995), "Public Spending and the Poor: Theory and Evidence". The World Bank.

World Development Report (1996). The World Bank. Oxford University Press.

World Bank (1999). Government Programs and Poverty in Mexico, Green Cover.

World Bank (1998). Country Economic Memorandum, "Factor Productivity and Growth". 



\section{Policy Research Working Paper Series}

Title

WPS2391 Cuts? Theory and Evidence for
Argentina
Author

Martin Ravallion

Dipak Dasgupta

Capital Flows to Developing Countries? Dilip Ratha

And How Does Official Lending

Respond?
WPS2393 Will the Euro Trigger More Monetary Unions in Africa?
Patrick Honohan
Philip R. Lane
Waly Wane
Remuneration of Heterogeneous
Inspectors Governance: A Cross-Country Empirical Analysis

WPS2397 Verifying Exchange Rate Regimes

WPS2398 Determinants of Current Account Deficits in Developing Countries

WPS2399 Managers, Investors, and Crises: Mutual Fund Strategies in Emerging Markets

WPS2400 Child Care and Women's Labor Force Participation in Romania

WPS2401 Telecom Traffic and Investment in Developing Countries: The Effects Of International Settlement Rate Reductions

WPS2402 Debt Management in Brazil: Evaluation of the Real Plan and Challenges Ahead

\section{Date}

July 2000

July 2000

July 2000

July 2000

July 2000

July 2000

Stephen Knack

Contact for paper

P. Sader 33902

S. Crow 30763

A. Yaptenco 31823

H. Sladovich 37658

H. Sladovich 37698

P. Sintim-Aboagye 38526

July 2000

E. Khine 37471 Eduardo Fajnzylber
Sergio Schmukler Luis Servén

César Calderón

July 2000

H. Vargas Alberto Chong Norman Loayza

Graciela Kaminsky

Richard Lyons Sergio Schmukler

July 2000

E. Khine

37471

Monica Fong

Michael Lokshin

July 2000

P. Sader 33902

Scott J. Wallsten

July 2000

P. Sintim-Aboagye 38526

Afonso S. Bevilaqua July 2000 S. Bery 85178 
Policy Research Working Paper Series

Title

WPS2403 Can the World Cut Poverty in Half? How Policy Reform and Effective Aid Can Meet International Development Goals

WPS2404 The Distribution of Mexico's Public Spending on Education
Author

Date

July 2000

Paul Collier

David Dollar

Gladys Lopez-Acevedo

Angel Salinas
Contact for paper

E. Khine 37471

M. Geller 85155 